\title{
La0.6Sr0.4Co0.2Fe0.803- nanofiber cathode for intermediate-temperature solid oxide fuel cells by water-based sol-gel electrospinning: Synthesis and electrochemical behaviour
}

Enrico, Anna; Zhang, Wenjing (Angela); Traulsen, Marie Lund; Sala, Elena Marzia; Costamagna, Paola; Holtappels, Peter

Published in:

Journal of the European Ceramic Society

Link to article, DOI:

10.1016/j.jeurceramsoc.2018.01.034

Publication date:

2018

Document Version

Peer reviewed version

Link back to DTU Orbit

Citation (APA):

Enrico, A., Zhang, W., Traulsen, M. L., Sala, E. M., Costamagna, P., \& Holtappels, P. (2018).

$\mathrm{La} \mathrm{Sr}$, $\mathrm{CO}_{\mathrm{Fe}} \mathrm{F}$ nanofiber cathode for intermediate-temperature solid oxide fuel cells by water-based sofogel efectrosfinning: Syjnthesis and electrochemical behaviour. Journal of the European Ceramic Society, 38(7), 2677-2686. https://doi.org/10.1016/j.jeurceramsoc.2018.01.034

\section{General rights}

Copyright and moral rights for the publications made accessible in the public portal are retained by the authors and/or other copyright owners and it is a condition of accessing publications that users recognise and abide by the legal requirements associated with these rights.

- Users may download and print one copy of any publication from the public portal for the purpose of private study or research.

- You may not further distribute the material or use it for any profit-making activity or commercial gain

- You may freely distribute the URL identifying the publication in the public portal 


\section{Accepted Manuscript}

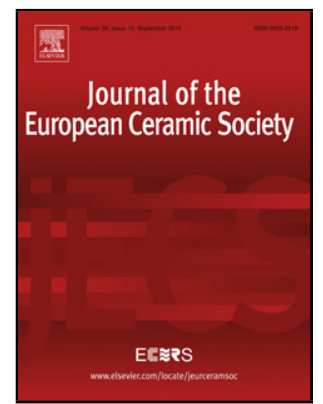

Authors: Anna Enrico, Wenjing Zhang, Marie Lund Traulsen, Elena Marzia Sala, Paola Costamagna, Peter Holtappels

PII:

S0955-2219(18)30049-9

DOI: https://doi.org/10.1016/j.jeurceramsoc.2018.01.034

Reference: JECS 11702

To appear in: $\quad$ Journal of the European Ceramic Society

Received date: $\quad 9-10-2017$

Revised date: $\quad 18-1-2018$

Accepted date: $\quad$ 21-1-2018

Please cite this article as: Enrico A, Zhang W, Traulsen ML, Sala EM, Costamagna $\mathrm{P}$, Holtappels $\mathrm{P}, \mathrm{La}_{0.6} \mathrm{Sr}_{0.4} \mathrm{Co}_{0.2} \mathrm{Fe}_{0.8} \mathrm{O}_{3 \text {-delta }}$ nanofiber cathode for intermediatetemperature solid oxide fuel cells by water-based sol-gel electrospinning: synthesis and electrochemical behaviour, Journal of The European Ceramic Society (2010), https://doi.org/10.1016/j.jeurceramsoc.2018.01.034

This is a PDF file of an unedited manuscript that has been accepted for publication. As a service to our customers we are providing this early version of the manuscript. The manuscript will undergo copyediting, typesetting, and review of the resulting proof before it is published in its final form. Please note that during the production process errors may be discovered which could affect the content, and all legal disclaimers that apply to the journal pertain. 
$\mathrm{La}_{0.6 \mathrm{Sr}}{ }_{0.4} \mathrm{Co}_{0.2} \mathrm{Fe}_{0.8} \mathrm{O}_{3-\delta}$ nanofiber cathode for intermediate-temperature solid oxide fuel cells by water-based sol-gel electrospinning: synthesis and electrochemical behaviour

by

Anna Enrico ${ }^{\mathrm{a}}$, Wenjing Zhang ${ }^{\mathrm{b}}$, Marie Lund Traulsen ${ }^{\mathrm{b}}$, Elena Marzia Sala ${ }^{\mathrm{a}}$, Paola Costamagna ${ }^{\mathrm{a} \dagger}$ and Peter Holtappels ${ }^{\mathrm{b} \dagger}$

${ }^{a}$ Department of Civil, Chemical and Environmental Engineering, University of Genoa, Via Opera Pia 15, 16145 Genoa, Italy.

${ }^{\mathrm{b}}$ Department of Energy Conversion and Storage, Technical University of Denmark, Risø Campus, Frederiksborgvej 399, DK-4000 Roskilde, Denmark.

† e-mail addresses: paola.costamagna@unige.it; peho@dtu.dk. 


\begin{abstract}
Water-based sol-gel electrospinning is employed to manufacture perovskite oxide $\mathrm{La}_{0.6} \mathrm{Sr}_{0.4} \mathrm{Co}_{0.2} \mathrm{Fe}_{0.8} \mathrm{O}_{3-\delta}$ (LSCF) nanofiber cathodes for intermediate-temperature solid oxide fuel cells. LSCF fibrous scaffolds are synthesized through electrospinning of a sol-gel solution employing water as the only solvent. Morphological characterizations demonstrate that the LSCF fibers have highly crystalline structure with uniform elemental distribution. After heat treatment, the average fiber diameter is $250 \mathrm{~nm}$ and the porosity of the nanofiber tissue is $37.5 \%$. The heat treated LSCF nanofibers are applied directly onto a $\mathrm{Ce}_{0.9} \mathrm{Gd}_{0.1} \mathrm{O}_{1.95}(\mathrm{CGO})$ electrolyte disk to form a symmetrical cell. Electrochemical characterization is carried out through electrochemical impedance spectroscopy (EIS) in the temperature range $550^{\circ} \mathrm{C}-950^{\circ} \mathrm{C}$, and reproducibility of the electrochemical performance for a series of cells is demonstrated. At $650^{\circ} \mathrm{C}$, the average measured polarization resistance Rp is 1.0 $\Omega \mathrm{cm}^{2}$. Measured performance decay is $1 \%$ during the first 33 hours of operation at $750^{\circ} \mathrm{C}$, followed by an additional $0.7 \%$ over the subsequent 70 hours.
\end{abstract}

\title{
Keywords
}

nanofiber; electrospinning; solid oxide fuel cell (SOFC); $\mathrm{La}_{1-\mathrm{x}} \mathrm{Sr}_{\mathrm{x}} \mathrm{Co}_{1-\mathrm{y}} \mathrm{Fe}_{\mathrm{y}} \mathrm{O}_{3-\delta}$ (LSCF); sol-gel synthesis. 


\section{Introduction}

One-dimensional materials made by electrospinning are being intensively investigated for application in the field of energy related systems $[1,2,3,4,5]$. Their unique structure provides low resistance to gas/liquid transport, high surface area, and efficient electron/ion transport along their longitudinal direction. Moreover, electrospinning offers absolutely unique possibilities of structuring complex networks at nanoscale using a rich variety of materials (e.g. polymer, ceramics and composites) [6] and with the ability to control composition, morphology and even secondary structure [7]. Such possibilities are particularly crucial in designing the electrodes for electrochemical cells, where mass transport properties, catalytic reaction sites and electron/ion conduction are important parameters to control for optimal cell performance. Moreover, electrospinning is considered the most efficient method of producing fibrous materials with advantages of simplicity, low cost, high yield and ease of up-scaling [8]. With recent developments in the design of electrospinning equipment and availability of industrial-scale electrospinning technologies with production rates of several thousands of square meters per day, new opportunities for electrospinning are imminent.

$\mathrm{La}_{1-\mathrm{x}} \mathrm{Sr}_{\mathrm{x}} \mathrm{Co}_{1-\mathrm{y}} \mathrm{Fe}_{\mathrm{y}} \mathrm{O}_{3-\delta}$ is a mixed ionic electronic conductor (MIEC) and is currently considered one of the most promising cathodes for Intermediate Temperature - Solid Oxide Fuel Cells (IT-SOFCs) due to the excellent balance of simultaneous electronic and ionic conductivities, as well as to the high electrocatalytic activity for the oxygen reduction reactions $[9,10,11,12,13,14]$. Performance improvement through infiltration or realization of composites with various types of ionic and electronic conductors has been investigated $[15,16,17,18,19,20,21,22,23]$. $\mathrm{La}_{1-\mathrm{x}} \mathrm{Sr}_{\mathrm{x}} \mathrm{Co}_{1-\mathrm{y}} \mathrm{Fe}_{\mathrm{y}} \mathrm{O}_{3-\delta}$ cathodes manufactured through the electrospinning method have recently been proposed and, following the latter approach, they have been infiltrated with gadolinia doped ceria $\left(\mathrm{CeO}_{2} / \mathrm{Gd}_{2} \mathrm{O}_{3}\right)[24,25,26,27,28,29,30,31,32]$, demonstrating improved performance over infiltrated conventional (i.e. non-electrospun) electrodes based on the same materials. However, the pristine 3-dimensional structure and the resulting electrochemical behaviour of the electrospun cathodes have received little attention so far. For example, Zhao et al. [24,26,28] tested pristine $\mathrm{La}_{0.8} \mathrm{Sr}_{0.2} \mathrm{Co}_{0.2} \mathrm{Fe}_{0.8} \mathrm{O}_{3-\delta}$ electrospun electrodes reporting an electrochemical performance in the range $\mathrm{R}_{\mathrm{p}}=1.6-14.1 \Omega \mathrm{cm}^{2}$ at $650^{\circ} \mathrm{C}$. In all the previous studies on electrospun electrodes for IT-SOFCs, the fibers were electrospun employing a starting solution obtained by dissolving precursor nitrates into dimethylformamide (DMF) and then adding polyvinylpyrrolidone (PVP) as a carrier polymer. 
The fibers obtained were heat treated, crashed and mixed with terpineol, to form an ink which was then applied onto the electrolyte disk. The final step was a firing at high temperature to realize the cells.

In the present work, we have developed a sol-gel solution for electrospinning with water as the only solvent. Such water-based electrospinning process offers safer operation and cheaper production for industrial applications, as compared to the processes based on toxic and expensive organic solvents. The composition investigated is $\mathrm{La}_{0.6} \mathrm{Sr}_{0.4} \mathrm{Co}_{0.2} \mathrm{Fe}_{0.8} \mathrm{O}_{3-\delta}$ (LSCF), which was demonstrated to be of particular interest in a previous study on the $\mathrm{La}_{1-\mathrm{x}} \mathrm{Sr}_{\mathrm{x}} \mathrm{Co}_{1}$ ${ }_{\mathrm{y}} \mathrm{Fe}_{\mathrm{y}} \mathrm{O}_{3-\delta}$ system [11,33]. Moreover, in this work the electrospun nanofiber electrodes have been directly applied onto the electrolyte disk without being crashed, to preserve the unique 3-dimensional fibrous structure.

The scope of the present work is to characterize pristine LSCF nanofiber cathodes prepared by this novel method, with respect to both physical structure and electrochemical performance.

\section{Experimental}

\subsection{Synthesis of LSCF nanofibers}

In this and the following section the synthesis of the LSCF nanofibers and the preparation of the electrochemical cells are explained in detail. The preparation process (Electronic Annex, EA, Tab. EA1) was based on a sol-gel assisted electrospinning method to synthesize ceramic nanofibers [7,34]. To prepare the electrospinning solution, the LSCF precursors were $\mathrm{La}\left(\mathrm{NO}_{3}\right)_{3} \cdot 6 \mathrm{H}_{2} \mathrm{O}, \quad \mathrm{Sr}\left(\mathrm{NO}_{3}\right)_{2}, \quad \mathrm{Co}\left(\mathrm{NO}_{3}\right)_{2} \cdot 6 \mathrm{H}_{2} \mathrm{O}$ and $\mathrm{Fe}\left(\mathrm{NO}_{3}\right)_{3} \cdot 9 \mathrm{H}_{2} \mathrm{O}$ at a molar ratio of 0.6:0.4:0.2:0.8. These were dissolved in de-ionized (DI) $\mathrm{H}_{2} \mathrm{O}$, which was used as solvent. Polyvinylpyrrolidone (PVP, $\left.\mathrm{M}_{\mathrm{w}}=1,300,000\right)$ was used as carrier polymer, with a weight ratio of PVP in solution 0.1 (corresponding to a weight ratio of PVP powder to overall solutes of about $25 \mathrm{wt} \%$ ). Higher ratio of PVP over nitrate salts resulted in finer or broken LSCF nanofibers after heat treatment; lower ratio of PVP resulted in electrosprayed droplets instead of nanofibers. After adding the PVP, the solution was stirred for $24 \mathrm{~h}$ until a clear and homogenous solution was formed. Experiments were carried out with an amount of $\mathrm{DI}_{2} \mathrm{O}$ solvent present in the solution varied between $55 \mathrm{wt} \%$ and $62 \mathrm{wt} \%$. The optimal composition 
of the solution was determined to be with $62 \mathrm{wt} \%$ water (see results section), and the recipe for this solution is reported in the EA, Tab. EA2.

The electrospinning laboratory equipment was RT Advanced by Linari Engineering. The precursor solution was loaded into a $10 \mathrm{ml}$ syringe with a 21 gauge stainless steel needle attached to the tip of the syringe. The syringe was then mounted on a syringe pump. During electrospinning, the precursor was pumped out of the needle at an injection rate of $0.3 \mathrm{ml} / \mathrm{h}$ with an electrical field of $4.4 \mathrm{kV} / \mathrm{cm}$. A grounded aluminum foil was used to collect the electrospun nanofibers. To promote water evaporation during the flight between needle and rotating collector, the chamber relative humidity was controlled at $20 \%$; simultaneously, temperature was kept at $29^{\circ} \mathrm{C}$. After deposition, the as-spun nanofiber tissue was peeled off from the foil and kept in air for $12 \mathrm{~h}$ to evaporate the solvent.

Then, the dried LSCF nanofiber tissue was cut in circular shape to obtain the electrodes and heat treated in a furnace at $800{ }^{\circ} \mathrm{C}$. The heat treatment profile was carefully designed to achieve both LSCF perovskite oxide phase as well as desired nano-morphological features of LSCF nanofibers. The details of the heating ramps are reported in EA, Tab. EA3. Most important, the heating rate between $350{ }^{\circ} \mathrm{C}$ and $500{ }^{\circ} \mathrm{C}$ was only $12{ }^{\circ} \mathrm{C} / \mathrm{h}$, due to the fact that the decomposition of PVP occurs in this temperature range, releasing excessive gases. The low heating rate was therefore chosen to provide sufficient time for gas diffusion from inside of the nanofiber to the surroundings. After thermal treatment, the LSCF nanofiber tissue was brought back to ambient temperature. The final area of the nanofiber tissue was $46 \%$ of that of the as-spun tissue, with uniform shrinkage in all the directions. In EA, Fig. EA1 reports an example of the nanofiber tissue before and after heat treatment. The heat treated LSCF circular electrodes had a diameter of $0.64 \mathrm{~cm}$ (electrode area $0.322 \mathrm{~cm}^{2}$ ).

\subsection{Preparation of symmetrical cells}

The $\mathrm{Ce}_{0.9} \mathrm{Gd}_{0.1} \mathrm{O}_{1.95}$ (CGO) electrolyte was made by tape casting, and the electrolyte disks were stamped out from the green tape and sintered with maximum sintering temperature $1250^{\circ} \mathrm{C}$. After sintering, the thickness of the CGO electrolyte disks was approximately 300 $\mu \mathrm{m}$ and the diameter was $1 \mathrm{~cm}$. To prepare the symmetrical cells, the heat treated LSCF nanofiber electrodes were applied on both sides of the CGO electrolyte disks. In order to ensure adhesion, the side of the LSCF electrode to be applied on the CGO disk was slightly humidified with the sol-gel electrospinning solution that was used to electrospin the LSCF nanofibers in this work. In that way, the formation of an interface between electrode and 
electrolyte was promoted, and the nanofibers to a large extent maintained the fibrous structure. Finally, before the electrochemical tests, the symmetrical cells were fired in situ at the maximum temperature of $950^{\circ} \mathrm{C}$ for 3 hours.

\subsection{Morphological characterization of fibers and symmetrical cells}

Scanning electron microscopy (SEM) and transmission electron microscopy (TEM) analyses of the cells was carried out before and after the electrochemical tests. The microstructure of the LSCF nano-fibers was investigated with SEM on a Zeiss Supra 35 microscope. For the SEM investigation, the InLens and the SE2 detector with $5 \mathrm{kV}$ acceleration voltage was used without any pre-treatment of the electrode. Furthermore, the thickness of the heat treated electrodes was investigated by SEM in a Hitachi TM3000 microscope. Prior to this investigation the cells were mounted in epoxy, polished and carbon coated. Image analysis was carried out using the software ImageJ, an open source Java image processing tool, together with DiameterJ, an open source tool created for ImageJ, allowing to evaluate characteristic geometrical features of the nanofiber structures in terms of porosity and size distribution [35]. A TEM specimen of the LSCF nanofibers after thermal treatment at $800{ }^{\circ} \mathrm{C}$ was prepared by dropping a small drop of ethanol solution containing LSCF nanofiber powders on a $\mathrm{Cu}$ TEM grid followed by drying at $60{ }^{\circ} \mathrm{C}$ in the air. TEM characterizations, including elemental mapping, were conducted in combination with EDX on a JEOL 3000F equipped with a $300 \mathrm{kV}$ field emission gun and an Oxford Instruments EDX detector with an ultra-thin window. XRD measurements were performed with a Bruker D8 X-ray Diffractometer (Bruker-Siemens, Germany) using $\mathrm{Cu} \mathrm{K} \alpha$ radiation with an acceleration voltage of $40 \mathrm{kV}$ and a filament current of $40 \mathrm{~mA}$.

\subsection{Electrochemical tests}

Four of the symmetrical cells described in the previous section were electrochemically characterized by means of electrochemical impedance spectroscopy (EIS). For the characterization, the cells were mounted in a four sample set-up in which each of the four cells was fixed between two gold meshes, which also acted as current collectors. The set-up was placed in a furnace, sealed and attached to the gas supply system. The impedance spectra were recorded in the temperature range between $550^{\circ} \mathrm{C}$ and $950^{\circ} \mathrm{C}$ in steps of $50{ }^{\circ} \mathrm{C}$, while the samples were exposed to a continuous flow of oxygen containing atmosphere (atmospheric pressure, with $\mathrm{p}_{\mathrm{O} 2}=0.20$ atm and balance Ar). The spectra were recorded in the frequency 
range $1 \cdot 10^{6} \mathrm{~Hz}$ to $0.01 \mathrm{~Hz}$ with a $10 \mathrm{mV}$ voltage amplitude using a Gamry Reference 600 potentiostat. The error on the impedance experimental measurements performed through the Gamry Reference 600 potentiostat, has been reported to be < 1\% [36].

The EIS spectra were fitted through the software Elchemea [37]. The fittings were based on equivalent circuits formed by $\mathrm{L}-\mathrm{R}_{\mathrm{s}}-\mathrm{Gd}-\mathrm{FLW}$ elements in series with each other, with $\mathrm{L}$ being an inductance, $R_{s}$ the serial resistance, Gd the depressed Gerischer element and FLW the Finite-Length-Warburg element. The mathematical expression for the depressed Gerischer element is:

$$
Z(\omega)=\frac{1}{Y(k+j \omega)^{n}} \quad \text { Eq. } 1
$$

The exponent $n$ is 0.5 for the normal Gerischer element $\mathrm{G}$, while values of $n$ lower than 0.5 allow to account for a suppressed or distorted Gerischer impedance response Gd. The mathematical expression for the FLW element is:

$$
Z(\omega)=\frac{\tanh (\sqrt{B j \omega)}}{\sqrt{Y_{1} j \omega}} \quad \text { Eq. } 2
$$

In the EIS Nyquist plots, the serial resistance $R_{s}$ corresponds to the high frequency intercept with the real axis. The polarization resistance $R_{p}$ has been evaluated as the difference between the low and high frequency intercepts of the Nyquist impedance spectra with the real axis. Concerning the uncertainty, the error has been evaluated to be $<2 \%$ for all the fitting results presented in the paper. 


\section{Results and discussion}

\subsection{Characterization of the electrospun fibers}

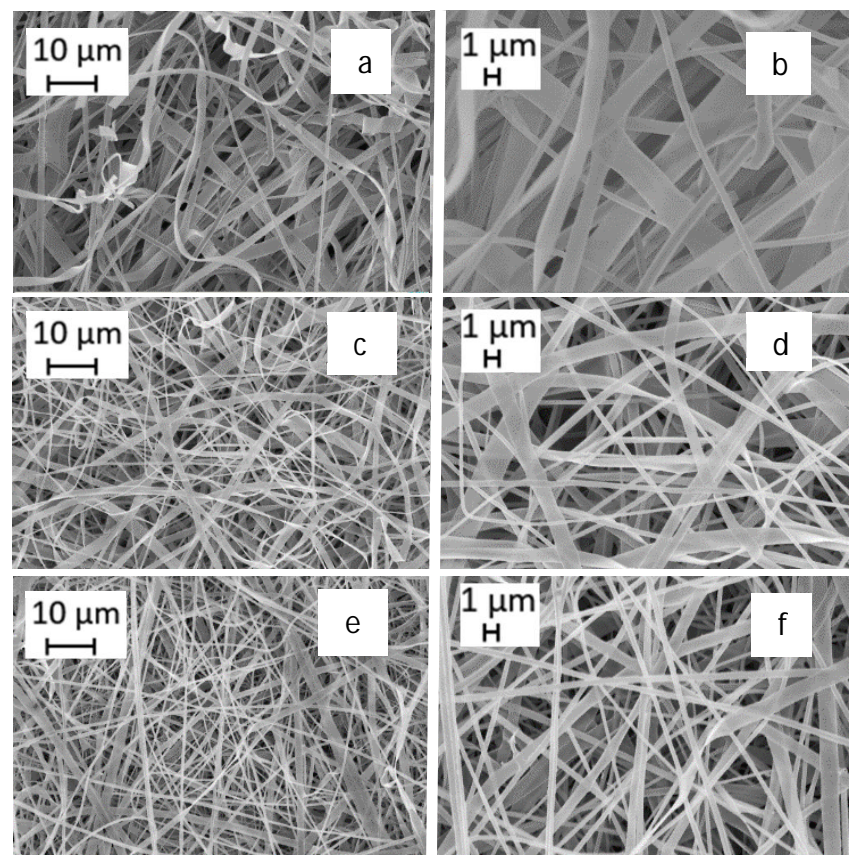

Figure 1 SEM pictures of LSCF as-spun fibers obtained with three different water contents: a,b) $55 \mathrm{wt} \%$, c,d) $59 \mathrm{wt} \%$ and e,f) $62 \mathrm{wt} \%$.

At first, the role of the amount of water present in the sol-gel electrospinning solution by varying the weight percentage of water has been analysed. The SEM images (Fig. 1) show the nanofiber tissue obtained for $55 \mathrm{wt} \%, 59 \mathrm{wt} \%$ and $62 \mathrm{wt} \%$ water, respectively, after the fibers had dried in air (step 2 in Tab. 1). The nanofibers manufactured with the lower amount of water (Fig. 1a and b) have a wide range of diameters and present some irregularities. The fibers become more uniform with the increase of the water content. For a water weight percentage of $62 \mathrm{wt} \%$ (Fig. 1e and f), we have obtained small diameters, distributed in a narrow range around the average value. The results from the image analysis, summarized in Tab. 1 (plots of fiber diameter frequency distributions in EA, Fig. EA2 and EA3) confirm this observation and show that the average fiber diameter decreases by increasing the water content of the starting solution, down to a value of $440 \mathrm{~nm}$ for the sample obtained from a starting solution with $62 \mathrm{wt} \%$ water content. Further SEM investigations not reported here display that, 
with $55 \mathrm{wt} \%$ and $59 \mathrm{wt} \%$ water content, the obtained nanofibers show irregular conformation, which is not observed with the $62 \mathrm{wt} \%$ water content. Thus, $62 \mathrm{wt} \%$ water has been used for preparation of the nanofiber electrodes tested electrochemically in this work.

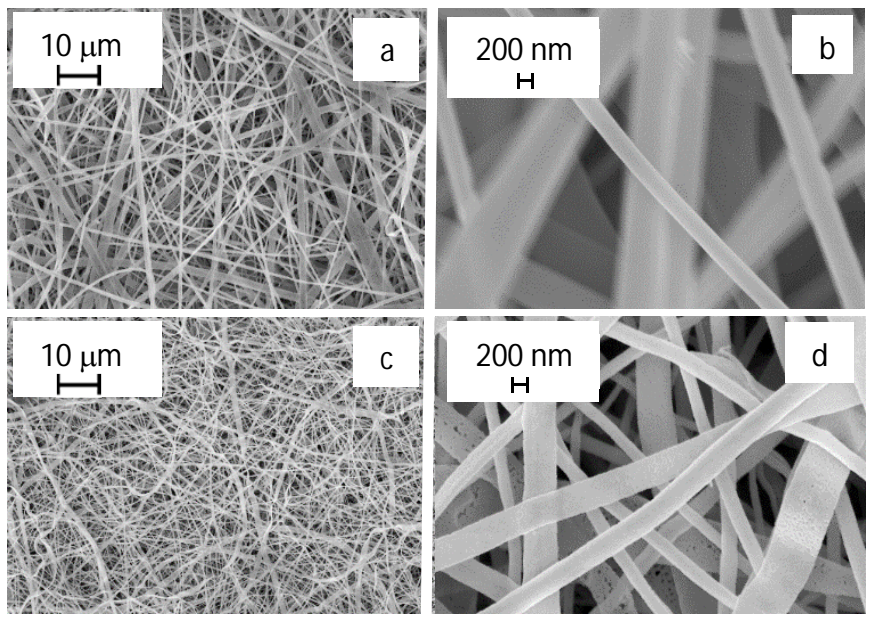

Figure 2 SEM pictures of LSCF fibers before $(a, b)$ and after $(c, d)$ heat treatment.

\begin{tabular}{|c|c|c|c|}
\hline Water content [wt\%] & Average Diameter [nm] & Porosity [\%] & Std. Dev. \\
\hline 55 & 930 (as spun) & 46.4 & 9.1 \\
\hline 59 & 450 (as spun) & 38.5 & 6.4 \\
\hline 62 & 440 (as spun) & 41.4 & 4.8 \\
\hline 62 & 250 (post heat treatment) & 37.5 & 6.3 \\
\hline
\end{tabular}

Table 1 Image analysis results for as-spun and heat- treated LSCF fibers obtained with various water contents (plots of fiber diameter frequency distributions in EA, Fig. EA2 and EA3).

Fig. 2 shows the SEM images of the as-spun fibers and after heat treatment. As reported in the experimental section, the sol-gel electrospinning solution contains a low amount of polymer ( $25 \mathrm{wt} \%$ in the as-spun nanofibers), resulting in a scarce reduction in fiber diameters after the heat treatment process. The image analysis results in Tab. 1 indicate that, after heat treatment, the average fiber diameter is $250 \mathrm{~nm}$ and porosity is $37.5 \%$, which is interesting in view of IT-SOFC applications, where small size electrode architectures and high electrode porosity are beneficial features [38]. 
To further evaluate the morphology and the crystalline structure of the LSCF nanofibers after heat treatment, TEM analysis with selected area diffraction (Fig. 3) has been carried out. The diffraction patterns in Fig. 3d show that the LSCF nanofibers have highly crystalline structure. This is further confirmed by the XRD patterns obtained from crushed calcined nanofibers (Fig. EA4 of the EA), which evidence the absence of secondary phases. In addition, elemental mapping analyses (Fig. EA5 of the EA) are used to visualize the distribution of each element inside the nanofibers, confirming that the mapping images of $\mathrm{La}, \mathrm{Sr}, \mathrm{Co}, \mathrm{Fe}$ and $\mathrm{O}$ show the same distributions along the fibers, resembling the nanofiber structure in the corresponding SEM image. There is no phase separation observed.

All the characterizations demonstrate the uniform elemental distribution and homogenous crystalline structure of the LSCF nanofibers synthesized through the sol-gel electrospinning method presented in this work.
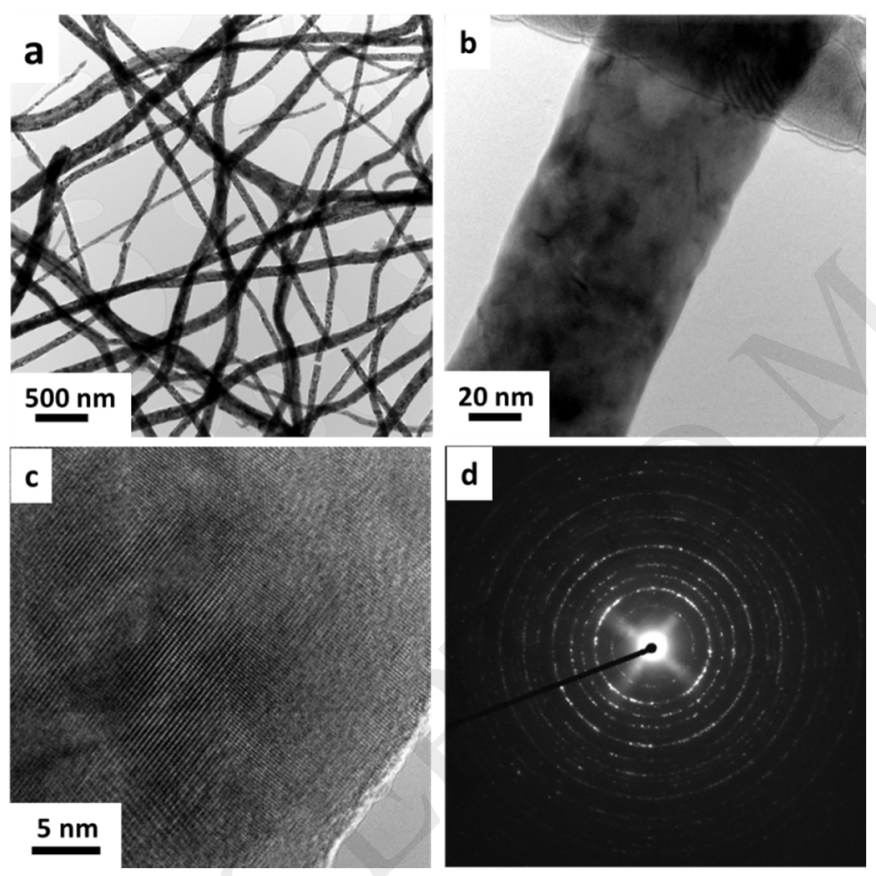

Figure 3 (a,b,c) TEM images of LSCF nanofibers after heat treatment; (d) image of selected area diffraction of the LSCF nanofibers in (a). 


\subsection{Morphological characterization of symmetrical cells}

Fig. 4 reports two images of the symmetrical cell after firing. Fig. 4a displays a top view of the LCSF fibrous electrode, showing that the fibrous structure is maintained during the process of cell preparation and subsequent calcination. Furthermore, Fig. 4a clearly shows that the fibers are lying on the 2-D electrolyte plane. The cross-section is investigated after breaking the symmetrical cell. Fig. 4b shows that the cross-section at the electrode-electrolyte interface exhibits a structure different from the top view presented in Fig. 4a. A general observation is that in some areas of the cell the fibers are very well-maintained, while in other areas they are collapsed into other structures, possibly due to the brittleness of ceramic materials. Further investigations are needed to explain the reason for these differences. Nevertheless, Fig. $4 \mathrm{~b}$ shows that there is good adhesion and no delamination between cathode and electrolyte, and that no significant residuals of the LSCF precursor sol-gel solution used to ensure adhesion between the electrodes and the electrolyte are visible.
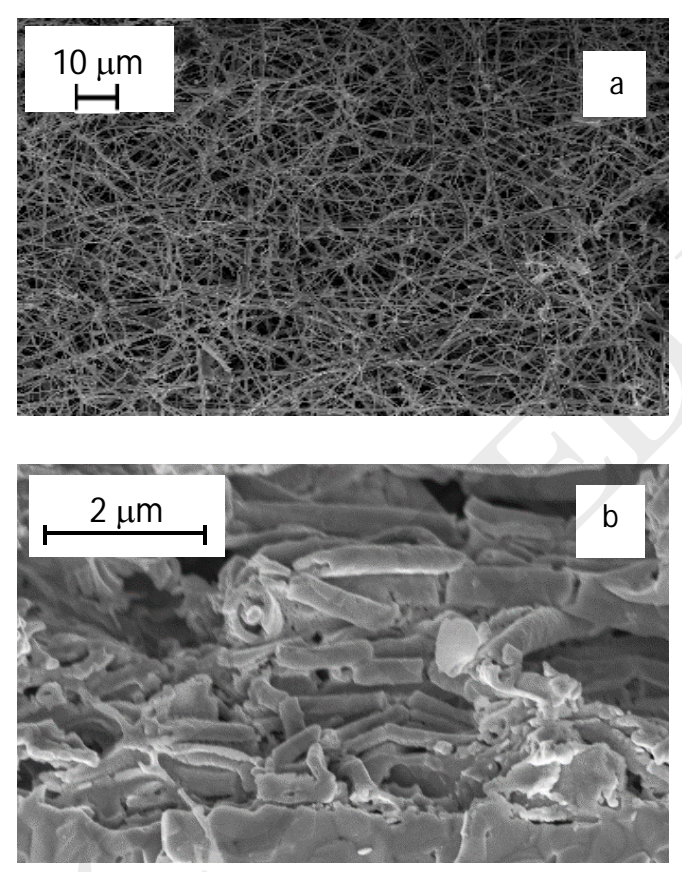

Figure 4 SEM image of LSCF nanofibers on the CGO electrolye after cell calcination (before the experimental electrochemical tests): (a) top view; (b) cross section obtained after breaking the cell. 


\subsection{Electrochemical characterization: EIS experimental results}

Representative experimental results from the electrochemical characterization are reported in Fig. 5, displaying the Nyquist plots of electrochemical impedance spectra recorded from one cell at $650^{\circ} \mathrm{C}, 800^{\circ} \mathrm{C}$ and $950^{\circ} \mathrm{C}$. At $650^{\circ} \mathrm{C}$ the experimental data show a single arc, which at high frequency turns into a straight line with $45^{\circ}$ slope with respect to the real axis. This is usually referred to as Gerischer behaviour [39,40,41]. With increasing temperature $\left(800^{\circ} \mathrm{C}\right.$ and $950^{\circ} \mathrm{C}$ ), this single arc gradually shrinks and gets deformed, with the high frequency straight line becoming remarkably narrower in range and reduced in slope, resulting in an overall arc depression. Furthermore, the shrinkage of the high frequency arc reveals a low frequency arc, whose dimensions and shape apparently do not change significantly with temperature, which suggests that this arc is related to the physical process of gas phase diffusion [42].

A direct comparison of the EIS results with previously published experimental data obtained from non-infiltrated $\mathrm{La}_{0.8} \mathrm{Sr}_{0.2} \mathrm{Co}_{0.2} \mathrm{Fe}_{0.8} \mathrm{O}_{3-\delta}$ electrospun nanofibers [24,26,28] is not possible, as literature only reports results obtained in the $650^{\circ} \mathrm{C}-750^{\circ} \mathrm{C}$ temperature range. However, the behaviour displayed in Fig. 5 is similar to that reported in the literature by Kournoutis et al. [43] for granular non-infiltrated $\mathrm{La}_{0.8} \mathrm{Sr}_{0.2} \mathrm{Co}_{0.2} \mathrm{Fe}_{0.8} \mathrm{O}_{3-\delta}$ electrodes at temperatures from $600^{\circ} \mathrm{C}$ to $850{ }^{\circ} \mathrm{C}$, and by Lee et al. [29] for electrospun $\mathrm{La}_{0.6} \mathrm{Sr}_{0.4} \mathrm{Co}_{0.2} \mathrm{Fe}_{0.8} \mathrm{O}_{3-\delta}-\mathrm{CGO}$ electrodes at temperatures from $550^{\circ} \mathrm{C}$ to $800{ }^{\circ} \mathrm{C}$. No fittings through equivalent circuit model are proposed for the EIS experimental arcs. Nielsen et al. [44] report EIS experimental spectra in the $550-850^{\circ} \mathrm{C}$ temperature range for granular $\left(\mathrm{La}_{0.6} \mathrm{Sr}_{0.4}\right)_{0.99} \mathrm{Co}_{0.2} \mathrm{Fe}_{0.8} \mathrm{O}_{3-\delta}-\mathrm{CGO}$ composite electrodes. The EIS spectra reported by Nielsen et al. display again a behavior analogous to that in Fig. 5, and fitting is conducted with an equivalent circuit model including an inductance $L$, a serial resistance $R_{s}$ and a Gerischer element $G$. The $L-R_{s}-G$ equivalent circuit model is demonstrated to provide satisfactory agreement in the temperature range $550^{\circ} \mathrm{C}-650^{\circ} \mathrm{C}$. In some cases, the finite length Gerischer element (FLG) is employed instead of the normal Gerischer in order to account for the depression of the high frequency arc. In the range of temperature $700^{\circ} \mathrm{C}-850^{\circ} \mathrm{C}$ the equivalent circuit employed is $\mathrm{L}-\mathrm{R}_{\mathrm{s}}-\mathrm{G}-\mathrm{FLW}$, including the finite length Warburg (FLW) element. In [44], it is demonstrated that the additional FLW element (Eq. 2) provides good fitting of the low frequency arc becoming visible at high temperatures.

In Fig. 5, together with the experimentally recorded EIS, fittings are reported as well. In agreement with what Nielsen at al. proposed, the equivalent circuit used for the fittings is L- 
$\mathrm{R}_{\mathrm{s}}-\mathrm{Gd}$ at $650^{\circ} \mathrm{C}$, and $\mathrm{L}-\mathrm{R}_{\mathrm{s}}-\mathrm{Gd}-\mathrm{FLW}$ at $800^{\circ} \mathrm{C}$ and $950^{\circ} \mathrm{C}$. In our case, the depressed Gerischer Gd circuit element is employed [37]. For the fittings displayed in Fig. 5, at $650^{\circ} \mathrm{C}$, where the arc is practically an ideal Gerischer, the value of $n$ (obtained from a best-fit [37]) is 0.466. At higher temperatures, were distortion and depression occurs, $\mathrm{n}=0.380$ at $800^{\circ} \mathrm{C}$ and finally $\mathrm{n}=0.229$ at $950^{\circ} \mathrm{C}$.

The fact that the Gd circuit element provides fully satisfactory fitting of the high frequency arc confirms that, also with the LSCF fibers under investigation, the underlying physical phenomenon is that typically represented by the Gerischer element, i.e. electrons and oxygen species transport along the paths offered by the LSCF fibers, coupled to distributed electrochemical reaction [24,26,28]. On the other hand, the good agreement between the low frequency experimental data at $800^{\circ} \mathrm{C}$ and $950^{\circ} \mathrm{C}$, and the fittings made through the FLW element, substantiates the hypothesis that, also with the LSCF fibers under consideration, the low frequency arc is due to gas diffusion. Indeed, it has been analytically demonstrated that gas diffusion in the pores or in a stagnant gas layer at the electrode surface results in a low frequency FLW impedance response [42]. It has been evaluated [44] that for the gases employed in fuel cells, bulk diffusion prevails at pore diameters greater than $\sim 10 \mu \mathrm{m}$, while Knudsen diffusion dominated at pore diameters less than 50-100 $\mathrm{nm}$. Considering the typical pore dimensions of granular electrodes, the conclusion [44] is that gas phase diffusion limitations occur not inside the electrode pores, but rather in the limiting gas diffusion layer adjacent to the electrode surface. This conclusion must hold also for electrospun electrodes, which have higher porosity than granular electrodes. 

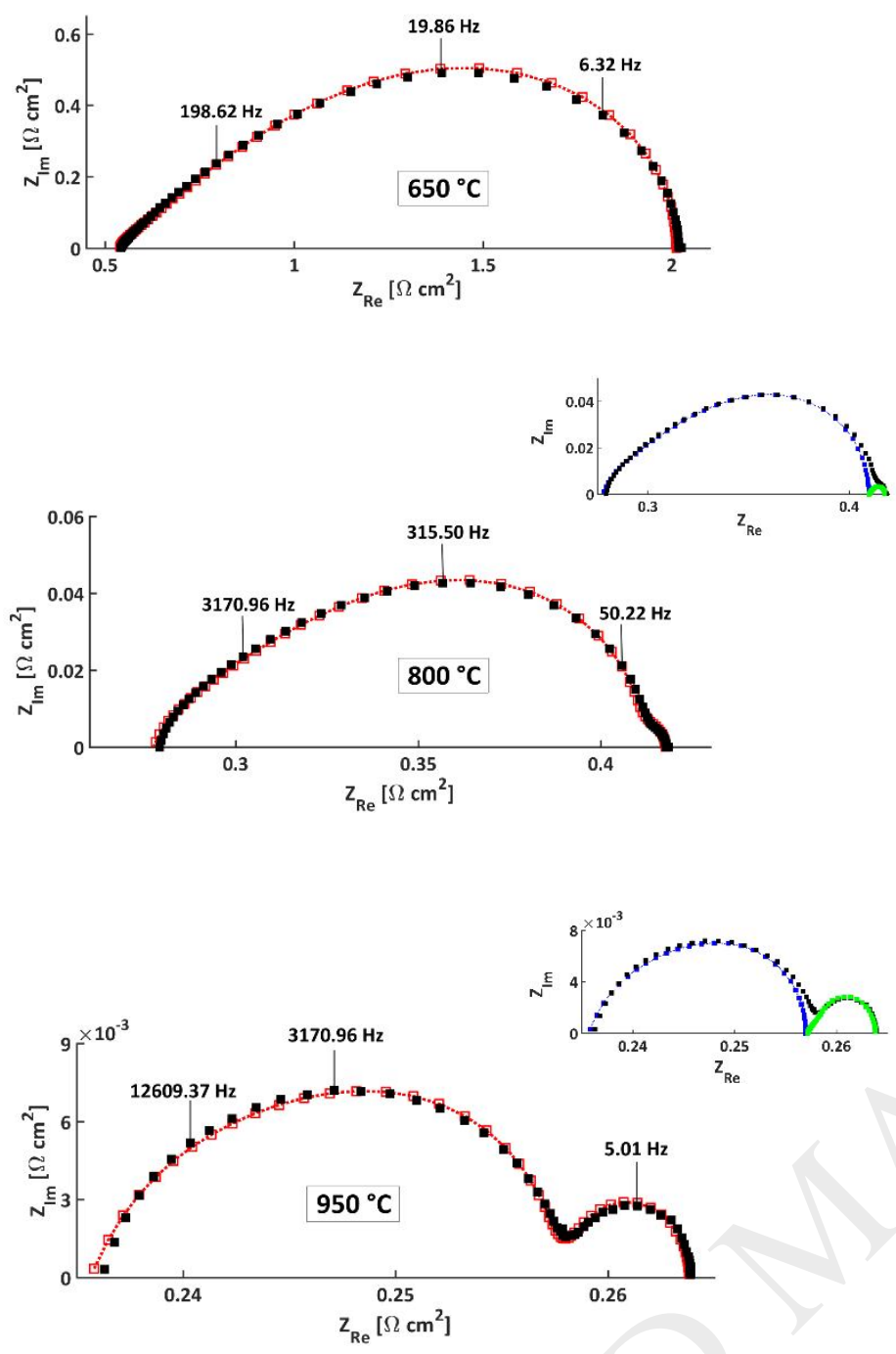

Figure 5 Nyquist plots of EIS experimental spectra $(\boldsymbol{\square})$ and fittings $(\cdots \square \cdots)$ for cell sample 2 at $650^{\circ} \mathrm{C}, 800^{\circ} \mathrm{C}$ and $950^{\circ} \mathrm{C}$. The EIS spectrum at $650^{\circ} \mathrm{C}$ is fitted with the $\mathrm{L}-\mathrm{R}_{\mathrm{s}}-\mathrm{Gd}$ equivalent circuit, while the data at $800^{\circ} \mathrm{C}$ and $950^{\circ} \mathrm{C}$ are fitted with the $\mathrm{L}-\mathrm{R}_{\mathrm{s}}-\mathrm{Gd}-\mathrm{FLW}$ equivalent circuit (where $L$ represents an inductance, $R_{s}$ the serial resistance, Gd the depressed Gerischer and FLW the finite-length-Warburg impedance element). The insets at $800^{\circ} \mathrm{C}$ and $950^{\circ} \mathrm{C}$ display the individual contributions of the depressed Gerischer $(\cdots \square \cdots)$ and Finite Length Warburg $(\cdots \cdots \cdots)$ fitting elements.

\subsection{Reproducibility in electrochemical performance and activation energies}

The overall electrode polarization resistance $R_{p}$ is evaluated as the difference between the low and high frequency intercepts of the Nyquist impedance spectra with the real axis. Through the fitting of the impedance spectra, the individual contribution of the Gd and FLW arcs to 
the overall polarization resistance can be evaluated again as the difference between the respective low and high frequency intercepts, as the following relationship holds:

$$
\mathrm{R}_{\mathrm{p}}=\mathrm{R}_{\mathrm{Gd}}+\mathrm{R}_{\mathrm{FLW}} \quad \text { Eq. } 3
$$

The insets in Fig. 5 display the individual Gd and FLW fittings and their intercepts with the real axis. In Fig. 6, 1/R $\mathrm{R}_{\mathrm{Gd}}$ and $1 / \mathrm{R}_{\mathrm{FLW}}$ are reported, in the form of Arrhenius plots, for four samples manufactured with identical procedure, and tested in the temperature range $550^{\circ} \mathrm{C}$ $950^{\circ} \mathrm{C}$. Fig. 6 demonstrates good repeatability. Some discrepancies are visible, which can be ascribed to minor uncertainties affecting the manufacturing and testing procedure.

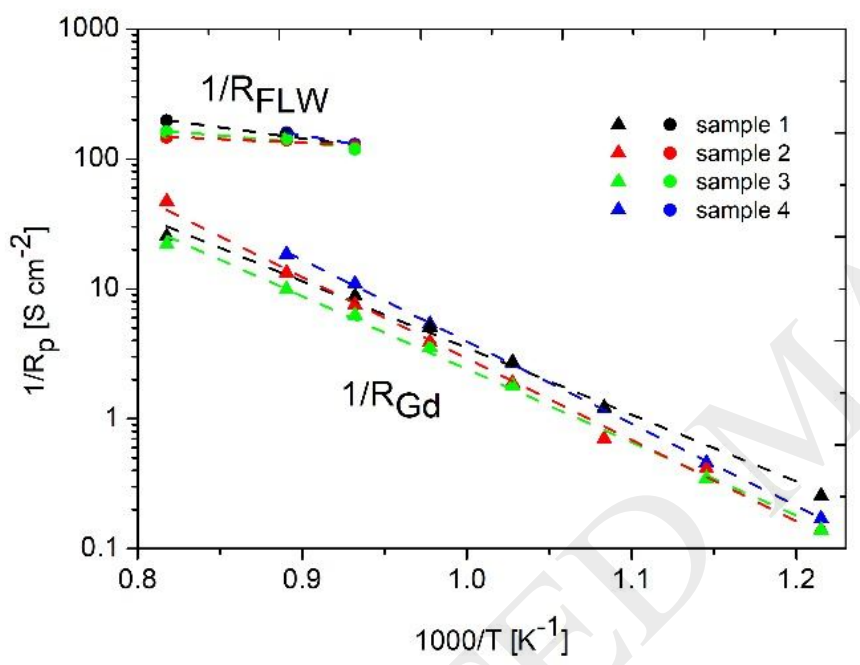

Figure 6 Arrhenius plot of the reciprocal polarization resistance associated to the depressed Gerischer EIS $\operatorname{arc}\left(1 / R_{\mathrm{Gd}}\right)$ and to the Finite Length Warburg EIS arc $\left(1 / \mathrm{R}_{\mathrm{FLW}}\right)$ for four identically manufactured samples.

The associated activation energies are reported in Tab. 2. For the Gerischer contribution $1 / \mathrm{R}_{\mathrm{Gd}}$, the activation energies are very close to each other (from 107.7 to $121.0 \mathrm{~kJ} / \mathrm{mol}$ ) for the four samples tested, confirming that the electrochemical process is the same. In principle, the FLW contribution is expected to be practically temperature independent [44]. Tab. 2 shows that the activation energies for $1 / \mathrm{R}_{\mathrm{FLW}}$ are remarkably lower than for the $1 / \mathrm{R}_{\mathrm{Gd}}$ contribution; however, it is difficult to draw a conclusion since activation energies are more scattered (between 11.0 
to $41.3 \mathrm{~kJ} / \mathrm{mol}$ ), which is in part due to the fact that, as displayed in Fig. 6, the calculation of the activation energy is based only upon three measurement points. Another comment is that the low frequency arc, even at the highest test temperature of $950^{\circ} \mathrm{C}$, is smaller than the high frequency arc. Fitting a small arc adjacent to a relatively large arc may result in more scattered fitting parameters. Finally, as discussed above, the FLW arc is associated to the diffusion process occurring in the boundary layer outside the electrode, where the current collector mesh is located. The placement of this mesh may be slightly different from one sample to the other, resulting in slight differences in the diffusion impedance.

In order to make a comparison with previously published results, we refer to data of activation energy of the overall $1 / R_{p}$, since this is more easily found in the literature than the activation energies of the individual contributions. To the best of the authors' knowledge, no data are reported in the literature for pristine electrospun $\mathrm{La}_{0.6} \mathrm{Sr}_{0.4} \mathrm{Co}_{0.2} \mathrm{Fe}_{0.8} \mathrm{O}_{3-\delta}$ electrodes. The only available literature data for pristine electrospun $\mathrm{La}_{0.8} \mathrm{Sr}_{0.2} \mathrm{Co}_{0.2} \mathrm{Fe}_{0.8} \mathrm{O}_{3-\delta}$ electrodes [28], report a value of $162.5 \mathrm{~kJ} / \mathrm{mol}$. For granular non-infiltrated $\mathrm{La}_{0.6} \mathrm{Sr}_{0.4} \mathrm{Co}_{0.2} \mathrm{Fe}_{0.8} \mathrm{O}_{3-\delta}$ electrodes, values ranging from $133.2 \mathrm{~kJ} / \mathrm{mol}$ to $148.6 \mathrm{~kJ} / \mathrm{mol}$ are reported [45,46,47]. For granular noninfiltrated $\mathrm{La}_{0.8} \mathrm{Sr}_{0.2} \mathrm{Co}_{0.2} \mathrm{Fe}_{0.8} \mathrm{O}_{3-\delta}$ electrodes, a value of $140.9 \mathrm{~kJ} / \mathrm{mol}$ is reported by [43], which is demonstrated to be in good agreement with several previous literature results. In presence of infiltrations or composites with CGO, the range of activation energies reported in the literature enlarges further. For a co-electrospun $\mathrm{La}_{0.6} \mathrm{Sr}_{0.4} \mathrm{Co}_{0.2} \mathrm{Fe}_{0.8} \mathrm{O}_{3-\delta}$-CGO electrode, Lee et al. [29] report an activation energy of $124.5 \mathrm{~kJ} / \mathrm{mol}$. Furthermore, Zhao et al. [28] report $115.2 \mathrm{~kJ} / \mathrm{mol}$ for electrospun $\mathrm{La}_{0.8} \mathrm{Sr}_{0.2} \mathrm{Co}_{0.2} \mathrm{Fe}_{0.8} \mathrm{O}_{3-\delta}$ electrodes infiltrated with CGO. These results only agree to a certain extent with previous literature data for granular electrodes with similar compositions. For example, for a composite electrode formed by $\left(\mathrm{La}_{0.6} \mathrm{Sr}_{0.4}\right)_{0.99} \mathrm{Co}_{0.2} \mathrm{Fe}_{0.8} \mathrm{O}_{3-\delta}$ and $\mathrm{CGO}$, an activation energy of $168 \mathrm{~kJ} / \mathrm{mol}$ is reported by Nielsen et al. [44], while values of 115.8-135.1 kJ/mol are reported by Wang et al. [15]. For CGO impregnated $\mathrm{La}_{0.8} \mathrm{Sr}_{0.2} \mathrm{Co}_{0.2} \mathrm{Fe}_{0.8} \mathrm{O}_{3-\delta}$ cathode, an activation energy of $159 \mathrm{~kJ} / \mathrm{mol}$ is reported by Chen et al. [48].

In this complex scenario, the average $1 / \mathrm{R}_{\mathrm{p}}$ activation energy of our $\mathrm{La}_{0.6} \mathrm{Sr}_{0.4} \mathrm{Co}_{0.2} \mathrm{Fe}_{0.8} \mathrm{O}_{3-\delta}$ electrodes $(106.6 \mathrm{~kJ} / \mathrm{mol})$ is in line with the previously reported data. It is interesting to notice that all the activation energies reported above fall in the range $105 \mathrm{~kJ} / \mathrm{mol}-186 \mathrm{~kJ} / \mathrm{mol}$. These are the activation energies reported by Steele et al. [49] for the oxygen surface exchange coefficient and the oxygen self-diffusion in LSCF respectively. Thus, activation energies close to $105 \mathrm{~kJ} / \mathrm{mol}$ suggest that the rate determining step is the oxygen surface exchange, and thus 
the charge transfer process. On the other hand, for activation energies close to $186 \mathrm{~kJ} / \mathrm{mol}$, the rate determining step appears to be the solid state oxygen transport through the MIEC. The average activation energy of $106.6 \mathrm{~kJ} / \mathrm{mol}$ for the reciprocal electrode polarization resistance $1 / R_{p}$, determined in this work, is at the lower end of the values reported in the literature, suggesting that the rate determining step is the oxygen surface exchange.

\begin{tabular}{|c|c|c|c|c|}
\cline { 2 - 5 } \multicolumn{1}{c|}{} & \multicolumn{4}{c|}{ Sample } \\
\hline Activation energy $\mathrm{E}_{\mathrm{a}}[\mathrm{kJ} / \mathrm{mol}]$ & 1 & 2 & 3 & 4 \\
\hline $1 / \mathrm{R}_{\mathrm{FLW}}$ & 32.7 & 11.0 & 21.2 & 41.3 \\
\hline $1 / \mathrm{R}_{\mathrm{Gd}}$ & 112.3 & 120.1 & 107.7 & 121.0 \\
\hline
\end{tabular}

Table 2 Activation energy Ea of the reciprocal polarization resistance associated to the depressed Gerischer EIS arc $\left(1 / R_{\mathrm{Gd}}\right)$ and to the Finite Length Warburg EIS arc (1/R $\left.\mathrm{R}_{\mathrm{FLW}}\right)$ for four identically manufactured samples.

Finally, the value of the serial resistance $R_{s}$ has been compared to the value calculated simply on the basis of the geometrical features (area and thickness) of the electrolyte and assuming a literature value for the ionic conductivity of the CGO electrolyte [50]. The difference is a value practically constant with temperature, and variable between 0.18 and $0.71 \Omega \mathrm{cm}^{2}$ for the four samples under consideration. This is ascribed to a non-ideal contact (contact resistance) between the various layers which form the cell, in particular between the fibers and the current collector placed on top of them.

\subsection{Electrochemical characterization: Stability test}

The results of a stability test are reported in Fig. 7, displaying the variation of $1 / R_{p}$ during 114 $\mathrm{h}$ of continuous operation at $750^{\circ} \mathrm{C}$. The initial value of $1 / \mathrm{R}_{\mathrm{p}}$ is assumed to be the $100 \%$ performance. Decay is faster at the beginning of the test, where $1 \%$ decay is detected in the first 33 hours of operation. Further decay is slower, i.e. $0.5 \%$ in the subsequent $38 \mathrm{~h}$ and finally an additional $0.24 \%$ over the subsequent $43 \mathrm{~h}$, indicating a tendency towards performance stabilization in the time frame investigated. 


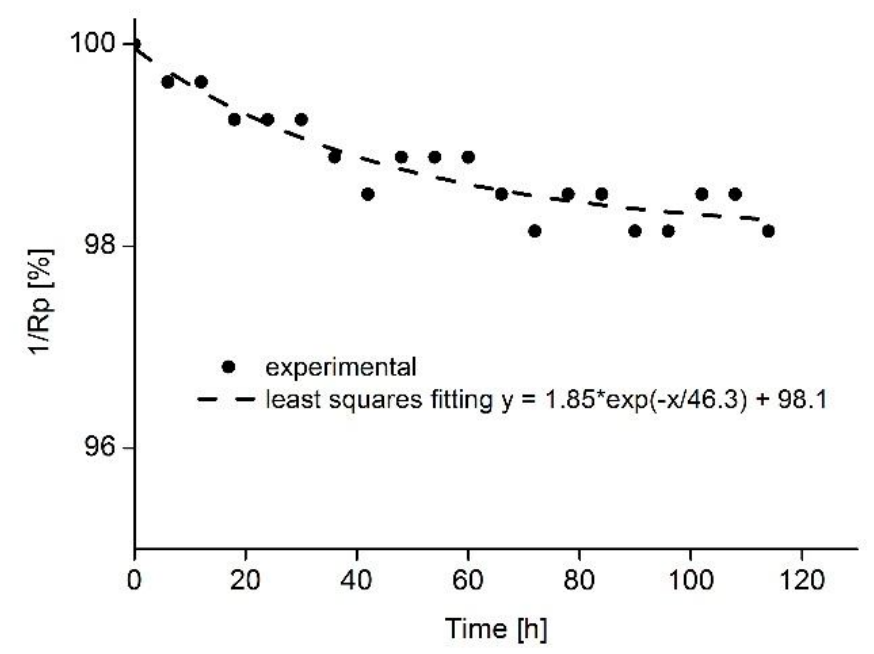

Figure 7 Decay of $1 / R_{p}$ during time for one sample electrospun electrode. Operating conditions: $\mathrm{T}=750^{\circ} \mathrm{C}, \mathrm{p}_{\mathrm{O} 2}=0.2 \mathrm{~atm}$.

\subsection{Critical assessment of the polarization resistance $R_{p}$}

Tab. 3 presents a comparison between the $\mathrm{R}_{\mathrm{p}}$ of the nanofibers presented in this work, and literature data obtained from non-infiltrated $\mathrm{La}_{1-\mathrm{x}} \mathrm{Sr}_{\mathrm{x}} \mathrm{Co}_{1-\mathrm{y}} \mathrm{Fe}_{\mathrm{y}} \mathrm{O}_{3-\delta}$ electrodes, granular or fibrous, with various size and internal $\mathrm{La}_{1-\mathrm{x}} \mathrm{Sr}_{\mathrm{x}} \mathrm{Co}_{1-\mathrm{y}} \mathrm{Fe}_{\mathrm{y}} \mathrm{O}_{3-\delta}$ compositions, tested at $650^{\circ} \mathrm{C}$ and oxygen partial pressure of $0.2 \mathrm{~atm}$. The value of $1.0 \Omega \mathrm{cm}^{2}$ reported for the present work is an average of the 4 different samples tested.

Fibrous $\mathrm{La}_{1-\mathrm{x}} \mathrm{Sr}_{\mathrm{x}} \mathrm{Co}_{1-\mathrm{y}} \mathrm{Fe}_{\mathrm{y}} \mathrm{O}_{3-\delta}$ electrodes are expected to provide improvement in electrochemical performance, if compared to granular ones, mainly due to their high surface area, which enhances the process of gas-solid oxygen surface exchange. Furthermore, the fibers offer longer continuous paths for ion and electron conduction through the electrode, with a reduced number of bottleneck contacts between one and another. However, it is interesting to notice (Tab. 3) that, in the literature, in some cases, performance significantly inferior has been observed for electrospun electrodes compared to granular electrodes. This has been explained in terms of poor geometrical features of the electrode/electrolyte interface. Indeed, the void degree of the fibrous structures is typically higher than with granular electrodes, which also means that the fiber/electrolyte effective contact, which is the three phase boundary (TPB) where the electrochemical reaction occurs, is smaller. Zhao et al. [28] have demonstrated that, by reducing the diameter of their $\mathrm{La}_{0.8} \mathrm{Sr}_{0.2} \mathrm{Co}_{0.2} \mathrm{Fe}_{0.8} \mathrm{O}_{3-\delta}$ fibers from 
200-300 $\mathrm{nm}$ to $100 \mathrm{~nm}$, it is possible to reduce the value of $\mathrm{R}_{\mathrm{p}}$ at $650^{\circ} \mathrm{C}$ from a value of 14.1 $\Omega \mathrm{cm}^{2}$ to $2.3 \Omega \mathrm{cm}^{2}$, as reported in Tab. 3. In that case, the electrospun fibers were calcinated and crashed before being applied onto the electrolyte disk. In the present work La0.6 $\mathrm{Sr}_{0.4} \mathrm{Co}_{0.2} \mathrm{Fe}_{0.8} \mathrm{O}_{3-\delta}$ electrospun electrodes are applied onto the electrolyte disk with a different procedure. During the electrospinning process, the nanofiber tissue is formed by laying a single fiber over a flat support surface for multiple times, forming a fiber bundle where the fibers are oriented mainly in-plane. The fibers are calcinated and then applied directly, without crashing, onto the electrolyte disk. For our nanofiber electrodes prepared with this approach, with an average diameter of $250 \mathrm{~nm}$ for the fibers, an $R_{p}$ of $1.0 \Omega \mathrm{cm}^{2}$ is obtained at $650^{\circ} \mathrm{C}$. This $\mathrm{R}_{\mathrm{p}}$ compares favourably to literature values (Tab. 3), being smaller than that of electrodes formed by $200-300 \mathrm{~nm}$ granules, and also smaller than that of the other nanotubes and nanorods based electrodes, where the electrode is applied on the electrolyte by procedures which involve crashing of the fibers. We assume that the low $R_{p}$ obtained in the present work to a large extent follows from a longer TPB obtained at the electrode/electrolyte interface, when the fibers are attached directly to the electrolyte without crashing. We believe that another factor responsible for the low $R_{p}$ obtained in the present work is the $\mathrm{La}_{0.6} \mathrm{Sr}_{0.4} \mathrm{Co}_{0.2} \mathrm{Fe}_{0.8} \mathrm{O}_{3-\delta}$ composition, which in previous literature studies has been demonstrated to be the best performing in the $\mathrm{La}_{1-\mathrm{x}} \mathrm{Sr}_{\mathrm{x}} \mathrm{Co}_{1-\mathrm{y}} \mathrm{Fe}_{\mathrm{y}} \mathrm{O}_{3-\delta}$ system [11].

\begin{tabular}{|l|l|l|l|l|}
\hline Composition and morphology & $\mathrm{d}[\mathrm{nm}]$ & $\begin{array}{l}\mathrm{R}_{\mathrm{p}} \\
{\left[\Omega \mathrm{cm}^{2}\right]}\end{array}$ & $\begin{array}{l}\mathrm{T} \\
{\left[{ }^{\circ} \mathrm{C}\right]}\end{array}$ & Reference \\
\hline $\mathrm{La} 0.8 \mathrm{Sr}_{0.2} \mathrm{Co}_{0.2} \mathrm{Fe}_{0.8} \mathrm{O}_{3-\delta}$ granular & 800 & 12.5 & 650 & {$[43]$} \\
\hline
\end{tabular}




\begin{tabular}{|l|l|l|l|l|}
\hline $\mathrm{La}_{0.6} \mathrm{Sr}_{0.4} \mathrm{Co}_{0.2} \mathrm{Fe}_{0.8} \mathrm{O}_{3-\delta}$ granular & $800-900$ & $4-10$ & 590 & {$[46]$} \\
\hline $\mathrm{La} 0.8 \mathrm{Sr}_{0.2} \mathrm{Co}_{0.5} \mathrm{Fe}_{0.5} \mathrm{O}_{3-\delta}$ granular & $200-300$ & 1.7 & 650 & {$[48]$} \\
\hline $\mathrm{La}_{0.6} \mathrm{Sr}_{0.4} \mathrm{Co}_{0.2} \mathrm{Fe}_{0.8} \mathrm{O}_{3-\delta}$ granular & 100 & 0.42 & 650 & {$[51]$} \\
\hline $\mathrm{La} 0.8 \mathrm{Sr}_{0.2} \mathrm{Co}_{0.2} \mathrm{Fe}_{0.8} \mathrm{O}_{3-\delta}$ nanorods & $200-300$ & 14.1 & 650 & {$[24]$} \\
\hline $\mathrm{La}_{0.8} \mathrm{Sr}_{0.2} \mathrm{Co}_{0.2} \mathrm{Fe}_{0.8} \mathrm{O}_{3-\delta}$ nanofibers & 100 & 2.3 & 650 & {$[28]$} \\
\hline $\mathrm{La}_{0.8} \mathrm{Sr}_{0.2} \mathrm{Co}_{0.2} \mathrm{Fe}_{0.8} \mathrm{O}_{3-\delta}$ nanotubes & $200-300$ & 1.6 & 650 & {$[26]$} \\
\hline $\mathrm{La}_{0.6} \mathrm{Sr}_{0.4} \mathrm{Co}_{0.2} \mathrm{Fe}_{0.8} \mathrm{O}_{3-\delta}$ nanofibers & 250 & 1.0 & 650 & $\begin{array}{l}\text { present } \\
\text { work }\end{array}$ \\
\hline
\end{tabular}

Table 3 Literature data for the electrode polarization resistance $\mathrm{R}_{\mathrm{p}}$ of $\mathrm{La}_{1-\mathrm{x}} \mathrm{Sr}_{\mathrm{x}} \mathrm{Co}_{1-\mathrm{y}} \mathrm{Fe}_{\mathrm{y}} \mathrm{O}_{3-\delta}$ cathodes (fibrous or granular).

As already mentioned in the introduction, many techniques have been reported in the literature aiming at improving the electrode performance, some of which are recalled here to provide a critical assessment of the results presented in this work, and also to provide a hint about the potential for further improvement. For example, Tab. 3 reports that Lou et al. [51] have obtained an $\mathrm{R}_{\mathrm{p}}=0.42 \Omega \mathrm{cm}^{2}$ with $100 \mathrm{~nm}$ granular $\mathrm{La}_{0.6} \mathrm{Sr}_{0.4} \mathrm{Co}_{0.2} \mathrm{Fe}_{0.8} \mathrm{O}_{3-\delta}$ electrode, which demonstrates that improvement can be obtained through further miniaturization of the internal electrode morphology. An additional confirmation is provided by the studies conducted by Ivers-Tiffée and co-workers [52,53,54,55], who have analyzed thin-film $\mathrm{La}_{0.6} \mathrm{Sr}_{0.4} \mathrm{CoO}_{3-\delta}$ cathodes obtained through metal organic deposition (MOD), with average grain and pore size in the sub-100nm regime (17 to $90 \mathrm{~nm}$ ), obtaining an $R_{p}$ as low as $910^{-3} \Omega \mathrm{cm}^{2}$ at $600^{\circ} \mathrm{C}$. The EIS spectra reported in [52], different from the spectra reported in the present work, display five distinct processes, suggesting a somehow different physical mechanism.

In addition to size reduction, other techniques of electrode improvement have been proposed, including infiltration $[15,16,17,18,19,20,21,22,23]$. Lou et al. [51] have reported that infiltration of $100 \mathrm{~nm}$ granular $\mathrm{La}_{0.6} \mathrm{Sr}_{0.4} \mathrm{Co}_{0.2} \mathrm{Fe}_{0.8} \mathrm{O}_{3-\delta}$ electrode with $\mathrm{Sm}_{0.5} \mathrm{Sr}_{0.5} \mathrm{CoO}_{3-\delta}$ decreases the $\mathrm{R}_{\mathrm{p}}$, at $650^{\circ} \mathrm{C}$, from $0.42 \Omega \mathrm{cm}^{2}$ to $0.12 \Omega \mathrm{cm}^{2}$. Infiltration has been demonstrated also with electrospun fiber electrodes [24,25,26,27,28,29,30,31,32]. In particular, Zhao et al. [26] have demonstrated that infiltration of 200-300 nm La ${ }_{0.8} \mathrm{Sr}_{0.2} \mathrm{Co}_{0.2} \mathrm{Fe}_{0.8} \mathrm{O}_{3-\delta}$ nanotubes with $\mathrm{Ce}_{0.8} \mathrm{Gd}_{0.2} \mathrm{O}_{1.9}$, decreases the $\mathrm{R}_{\mathrm{p}}$ at $650^{\circ} \mathrm{C}$ from $1.6 \Omega \mathrm{cm}^{2}$ to $0.07 \Omega \mathrm{cm}^{2}$. 
Thus altogether these results from literature show a comparable or even better electrode performance, compared to the present work, for electrodes where the nanostructure has been further optimized. This points in the direction that the performance of the already promising nanofiber electrodes presented in this work, may be further improved by careful optimization of their nanostructure, for instance through infiltration.

\section{Conclusions}

We have investigated $\mathrm{La}_{0.6} \mathrm{Sr}_{0.4} \mathrm{Co}_{0.2} \mathrm{Fe}_{0.8} \mathrm{O}_{3-\delta}$ fibrous cathodes for IT-SOFC applications, fabricated through water based sol-gel electrospinning. Water-based electrospinning offers safer operation and cheaper production costs, compared to processes based on toxic and expensive organic solvents. The electrospun $\mathrm{La}_{0.6} \mathrm{Sr}_{0.4} \mathrm{Co}_{0.2} \mathrm{Fe}_{0.8} \mathrm{O}_{3-\delta}$ nanofibers have been heat treated and then applied directly, without crashing, onto a CGO electrolyte disk. The as-spun nanofibers and electrodes have been characterised morphologically, and the electrochemical performance of the nanofiber electrodes has been evaluated through EIS. The EIS experimental results obtained at $650^{\circ} \mathrm{C}$ display a single arc. This arc is well fitted through the Gerischer element, which provides a representation of the physical process of charge transport in the electrode, coupled to a distributed electrochemical reaction. In the temperature range $800-950^{\circ} \mathrm{C}$, the Gerischer arc shrinks allowing the progressive appearance of an additional arc in the low frequencies domain, which is well fitted through a finite length Warburg (FLW) element, representing the physical process of gas phase diffusion.

The average polarization resistance calculated from the EIS experimental results is $R_{p}=1.0$ $\Omega \mathrm{cm}^{2}$ at $650^{\circ} \mathrm{C}$, lower than that of previous literature $\mathrm{La}_{1-\mathrm{x}} \mathrm{Sr}_{\mathrm{x}} \mathrm{Co}_{1-\mathrm{y}} \mathrm{Fe}_{\mathrm{y}} \mathrm{O}_{3}$ electrodes formed by (a) granules of comparable size, (b) electrospun nano-rods of the same size, and (c) finer nanofibers. We assume that the low $\mathrm{R}_{\mathrm{p}}$ in the present work follows from a longer TPB obtained at the electrode/electrolyte interface, when the fibers are attached directly to the electrolyte without crashing, and also from the $\mathrm{La}_{0.6} \mathrm{Sr}_{0.4} \mathrm{Co}_{0.2} \mathrm{Fe}_{0.8} \mathrm{O}_{3-\delta}$ composition, which in previous literature studies has been demonstrated to be the best performing in the $\mathrm{La}_{1-\mathrm{x}} \mathrm{Sr}_{\mathrm{x}} \mathrm{Co}_{1-\mathrm{y}} \mathrm{Fe}_{\mathrm{y}} \mathrm{O}_{3-\delta}$ system [11]. The low $\mathrm{R}_{\mathrm{p}}$ suggests that the electrodes manufactured with the novel procedure presented in this paper will display interesting performance when infiltrated. The high degree of porosity of the fibrous nano-structure is expected to accommodate a high concentration of infiltrations, further extending the TPB and thus the electrochemical reaction inside the 
electrode thickness. This advantage is expected to combine positively with the good charge transfer properties of the electrode/electrolyte interface discussed in the present work.

In the future, more work is needed to clarify the exact extension of the TPB when the nanofiber electrodes are prepared by the method described herein, just as the mechanical strength of the electrodes requires further attention. Another topic of further investigation is the possibility of upscaling the manufacturing process. Indeed, the method of making an LSCF tissue and then applying it directly onto the electrolyte is demonstrated here for a button cell; scaling up to larger sizes needs specific investigations.

\section{Acknowledgements}

A.E. and E. M. S. gratefully acknowledge the group at DTU for kind hospitality and supervision during research stay and Erasmus+ respectively. Authors also thank Hans Christian Ørsted Postdoc Fellowship for providing funding to the electrospinning part of the project. 


\section{References}

[1] Hochbaum, A. I., \& Yang, P. (2010). Semiconductor nanowires for energy conversion. Chemical Reviews, 110(1), 527-546. doi:10.1021/cr900075v

[2] Zhang, W., \& Pintauro, P. N. (2011). High-performance nanofiber fuel cell electrodes. ChemSusChem, 4(12), 1753-1757. doi:10.1002/cssc.201100245

[3] Sood, R., Cavaliere, S., Jones, D.J., \& Rozière, J. (2016). Electrospun nanofibre composite polymer electrolyte fuel cell and electrolysis membranes. Nano Energy, 26, 729-745. doi:10.1016/j.nanoen.2016.06.027

[4] Cavaliere, S., Subianto, S., Savych, I., Jones, D. J., \& Rozière, J. (2011). Electrospinning: Designed architectures for energy conversion and storage devices. Energy and Environmental Science, 4(12), 4761-4785. doi:10.1039/c1ee02201f

[5] Choi, J., Kim, B., \& Shin, D. (2013). Performance evaluation of $\mathrm{Sm}_{0.5} \mathrm{Sr}_{0.5} \mathrm{CoO}_{3-\delta}$ fibers with embedded $\mathrm{Sm}_{0.2} \mathrm{Ce}_{0.8} \mathrm{O}_{1.9}$ particles as a solid oxide fuel cell composite cathode. Journal of the European Ceramic Society, 33(12), 2269-2273. doi:10.1016/j.jeurceramsoc.2013.01.015

[6] Jung, J. -., Lee, C. -., Yu, S., \& Kim, I. -. (2016). Electrospun nanofibers as a platform for advanced secondary batteries: A comprehensive review. Journal of Materials Chemistry A, 4(3), 703-750. doi:10.1039/c5ta06844d

[7] Simonsen, S. B., Shao, J., \& Zhang, W. (2017). Structural evolution during calcination and sintering of a $\left(\mathrm{La}_{0.6} \mathrm{Sr}_{0.4}\right)_{0.99} \mathrm{CoO}_{3-\delta}$ nanofiber prepared by electrospinning. Nanotechnology, 28(26). doi:10.1088/1361-6528/aa73a6

[8] Persano, L., Camposeo, A., Tekmen, C., \& Pisignano, D. (2013). Industrial upscaling of electrospinning and applications of polymer nanofibers: A review. Macromolecular Materials and Engineering, 298(5), 504-520. doi:10.1002/mame.201200290

[9] Richter, J., Holtappels, P., Graule, T., Nakamura, T., \& Gauckler, L. J. (2009). Materials design for perovskite SOFC cathodes. Monatshefte Fur Chemie, 140(9), 985-999. doi:10.1007/s00706-009-0153-3

[10] Tai, L. -., Nasrallah, M. M., Anderson, H. U., Sparlin, D. M., \& Sehlin, S. R. (1995). Structure and electrical properties of $\mathrm{La}_{1-\mathrm{x}} \mathrm{Sr}_{\mathrm{x}} \mathrm{Co}_{1-\mathrm{y}} \mathrm{Fe}_{\mathrm{y}} \mathrm{O}_{3}$. part 1. the system $\mathrm{La}_{0.8} \mathrm{Sr}_{0.2} \mathrm{Co}_{1-\mathrm{y}} \mathrm{Fe}_{\mathrm{y}} \mathrm{O}_{3}$. Solid State Ionics, 76(3-4), 259-271. doi:10.1016/0167-2738(94)00244-M

[11] Tai, L. -., Nasrallah, M. M., Anderson, H. U., Sparlin, D. M., \& Sehlin, S. R. (1995). Structure and electrical properties of $\mathrm{La}_{1-\mathrm{x}} \mathrm{Sr}_{\mathrm{x}} \mathrm{Co}_{1-\mathrm{y}} \mathrm{Fe}_{\mathrm{y}} \mathrm{O}_{3}$. part 2. the system $\mathrm{La}_{1-\mathrm{x}} \mathrm{Sr}_{\mathrm{x}} \mathrm{Co}_{0.2} \mathrm{Fe}_{0.8} \mathrm{O}_{3}$. Solid State Ionics, 76(3-4), 273-283. doi:10.1016/0167-2738(94)00245-N

[12] Stevenson, J. W., Armstrong, T. R., Carneim, R. D., Pederson, L. R., \& Weber, W. J. (1996). Electrochemical properties of mixed conducting perovskites $\mathrm{La}_{1-\mathrm{x}} \mathrm{M}_{\mathrm{x}} \mathrm{Co}_{1-\mathrm{y}} \mathrm{Fe}_{\mathrm{y}} \mathrm{O}_{3-\delta}(\mathrm{M}=\mathrm{Sr}, \mathrm{Ba}$, Ca). Journal of the Electrochemical Society, 143(9), 2722-2729. 
[13] Im, H. -., Choi, M. -., Singh, B., Lim, D. -., \& Song, S. -. (2015). Investigation of oxygen reduction reaction on $\mathrm{La}_{0.1} \mathrm{Sr}_{0.9} \mathrm{Co}_{0.8} \mathrm{Fe}_{0.2} \mathrm{O}_{3-\delta}$ electrode by electrochemical impedance spectroscopy. Journal of the Electrochemical Society, 162(7), F728-F735. doi:10.1149/2.0581507jes

[14] Sun, C., Hui, R., \& Roller, J. (2010). Cathode materials for solid oxide fuel cells: A review. Journal of Solid State Electrochemistry, 14(7), 1125-1144. doi:10.1007/s10008-009-0932-0

[15] Wang, W. G., \& Mogensen, M. (2005). High-performance lanthanum-ferrite-based cathode for SOFC. Solid State Ionics, 176(5-6), 457-462. doi:10.1016/j.ssi.2004.09.007

[16] Perry Murray, E., Sever, M. J., \& Barnett, S. A. (2002). Electrochemical performance of $(\mathrm{La}, \mathrm{Sr})(\mathrm{Co}, \mathrm{Fe}) \mathrm{O}_{3}-(\mathrm{Ce}, \mathrm{Gd}) \mathrm{O}_{3}$ composite cathodes. Solid State Ionics, 148(1-2), 27-34. doi:10.1016/S0167-2738(02)00102-9

[17] Sakito, Y., Hirano, A., Imanishi, N., Takeda, Y., Yamamoto, O., \& Liu, Y. (2008). Silver infiltrated $\mathrm{La}_{0.6} \mathrm{Sr}_{0.4} \mathrm{Co}_{0.2} \mathrm{Fe}_{0.8} \mathrm{O}_{3}$ cathodes for intermediate temperature solid oxide fuel cells. Journal of Power Sources, 182(2), 476-481. doi:10.1016/j.jpowsour.2008.04.052

[18] Sahibzada, M., Benson, S. J., Rudkin, R. A., \& Kilner, J. A. (1998). Pd-promoted $\mathrm{La}_{0.6} \mathrm{Sr}_{0.4} \mathrm{Co}_{0.2} \mathrm{Fe}_{0.8} \mathrm{O}_{3}$ cathodes. Solid State Ionics, 113-115, 285-290.

[19] Chen, J., Liang, F., Liu, L., Jiang, S., Chi, Pu, J., \& Li, J. (2008). Nano-structured $(\mathrm{La}, \mathrm{Sr})(\mathrm{Co}, \mathrm{Fe}) \mathrm{O}_{3}+\mathrm{YSZ}$ composite cathodes for intermediate temperature solid oxide fuel cells. Journal of Power Sources, 183(2), 586-589. doi: 10.1016/j.jpowsour.2008.05.082

[20] Haanappel, V. A. C., Rutenbeck, D., Mai, A., Uhlenbruck, S., Sebold, D., Wesemeyer, H., . . . Tietz, F. (2004). The influence of noble-metal-containing cathodes on the electrochemical performance of anode-supported SOFCs. Journal of Power Sources, 130(1-2), 119-128. doi:10.1016/j.jpowsour.2003.11.046

[21] Lee, S., Song, H. S., Hyun, S. H., Kim, J., \& Moon, J. (2010). LSCF-SDC core-shell highperformance durable composite cathode. Journal of Power Sources, 195(1), 118-123. doi:10.1016/j.jpowsour.2009.06.079

[22] Qiang, F., Sun, K., Zhang, N., Zhu, X., Le, S., \& Zhou, D. (2007). Characterization of electrical properties of GDC doped A-site deficient LSCF based composite cathode using impedance spectroscopy. Journal of Power Sources, 168(2), 338-345. doi:10.1016/j.jpowsour.2007.03.040

[23] Shah, M., \& Barnett, S. A. (2008). Solid oxide fuel cell cathodes by infiltration of $\mathrm{La}_{0.6} \mathrm{Sr}_{0.4} \mathrm{Co}_{0.2} \mathrm{Fe}_{0.8} \mathrm{O}_{3-\delta}$ into Gd-doped ceria. Solid State Ionics, 179(35-36), 2059-2064. doi:10.1016/j.ssi.2008.07.002

[24] Zhao, E., Jia, Z., Zhao, L., Xiong, Y., Sun, C., \& Brito, M. E. (2012). One dimensional $\mathrm{La}_{0.8} \mathrm{Sr}_{0.2} \mathrm{Co}_{0.2} \mathrm{Fe}_{0.8} \mathrm{O}_{3-\delta} / \mathrm{Ce}_{0.8} \mathrm{Gd}_{0.2} \mathrm{O}_{1.9}$ nanocomposite cathodes for intermediate temperature solid oxide fuel cells. Journal of Power Sources, 219, 133-139. doi:10.1016/j.jpowsour.2012.07.013 
[25] Zhi, M., Lee, S., Miller, N., Menzler, N. H., \& Wu, N. (2012). An intermediate-temperature solid oxide fuel cell with electrospun nanofiber cathode. Energy and Environmental Science, 5(5), 7066-7071. doi:10.1039/c2ee02619h

[26] Zhao, E., Ma, C., Yang, W., Xiong, Y., Li, J., \& Sun, C. (2013). Electrospinning $\mathrm{La}_{0.8} \mathrm{Sr}_{0.2} \mathrm{Co}_{0.2} \mathrm{Fe}_{0.8} \mathrm{O}_{3-\delta}$ tubes impregnated with $\mathrm{Ce}_{0.8} \mathrm{Gd}_{0.2} \mathrm{O}_{1.9}$ nanoparticles for an intermediate temperature solid oxide fuel cell cathode. International Journal of Hydrogen Energy, 38(16), 6821-6829. doi:10.1016/j.ijhydene.2013.03.111

[27] Lee, J. G., Lee, C. M., Park, M. G., Jung, S. -., \& Shul, Y. G. (2013). Performance evaluation of anode-supported $\mathrm{Gd}_{0.1} \mathrm{Ce}_{0.9} \mathrm{O}_{1.95}$ cell with electrospun $\mathrm{La}_{0.6} \mathrm{Sr}_{0.4} \mathrm{Co}_{0.2} \mathrm{Fe}_{0.8} \mathrm{O}_{3-\delta}-\mathrm{Gd}$ ${ }_{0.1} \mathrm{Ce}_{0.9} \mathrm{O}_{1.95}$ cathode. Electrochimica Acta, 108, 356-360. doi:10.1016/j.electacta.2013.06.091

[28] Zhao, E., Liu, X., Liu, L., Huo, H., \& Xiong, Y. (2014). Effect of $\mathrm{La}_{0.8} \mathrm{Sr}_{0.2} \mathrm{Co}_{0.2} \mathrm{Fe}_{0.8} \mathrm{O}_{3-\delta}$ morphology on the performance of composite cathodes. Progress in Natural Science: Materials International, 24(1), 24-30. doi:10.1016/j.pnsc.2014.01.008

[29] Lee, J. G., Park, M. G., Park, J. H., \& Shul, Y. G. (2014). Electrochemical characteristics of electrospun $\mathrm{La}_{0.6} \mathrm{Sr}_{0.4} \mathrm{Co}_{0.2} \mathrm{Fe}_{0.8} \mathrm{O}_{3-\delta}-\mathrm{Gd}_{0.1} \mathrm{Ce}_{0.9} \mathrm{O}_{1.95}$ cathode. Ceramics International, 40(6), 8053-8060. doi:10.1016/j.ceramint.2013.12.158

[30] Zhao, E., Jia, Z., Liu, X., Gao, K., Huo, H., \& Xiong, Y. (2014). Stability of nanorodstructured $\mathrm{La} 0.8 \mathrm{Sr}_{0.2} \mathrm{Co}_{0.2} \mathrm{Fe}_{0.8} \mathrm{O}_{3-\delta}-\mathrm{Gd}_{0.2} \mathrm{Ce}_{0.8} \mathrm{O}_{1.9}$ composite cathodes for intermediate temperature solid oxide fuel cells. Ceramics International, 40(9 PART B), 14891-14898. doi:10.1016/j.ceramint.2014.06.084

[31] Lubini, M., Chinarro, E., Moreno, B., Jurado, J. R., de Sousa, V. C., Alves, A. K., . . . Bergmann, C. P. (2017). Electrochemical characteristics of $\mathrm{La}_{0.6} \mathrm{Sr}_{0.4} \mathrm{Co}_{1-\mathrm{y}} \mathrm{Fe}_{\mathrm{y}} \mathrm{O}_{3}(\mathrm{y}=0.2-1.0)$ fiber cathodes. Ceramics International, 43(12), 8715-8720. doi:10.1016/j.ceramint.2017.04.002

[32] Aruna, S. T., Balaji, L. S., Kumar, S. S., \& Prakash, B. S. (2017). Electrospinning in solid oxide fuel cells - A review. Renewable and Sustainable Energy Reviews, 67, 673-682. doi:10.1016/j.rser.2016.09.003

[33] Perry, N. H., \& Ishihara, T. (2016). Roles of bulk and surface chemistry in the oxygen exchange kinetics and related properties of mixed conducting perovskite oxide electrodes. Materials, 9(10). doi:10.3390/ma9100858

[34] Enrico, A., Aliakbarian, B., Lagazzo, A., Donazzi, A., Botter, R., Perego, P., \& Costamagna P. (2017). Parameter optimization for the electrospinning of $\mathrm{La}_{1-\mathrm{x}} \mathrm{Sr}_{\mathrm{x}} \mathrm{Co}_{1-\mathrm{y}} \mathrm{Fe}_{\mathrm{y}} \mathrm{O}_{3-\Delta}$ fibers for IT-SOFC electrodes. Fuel Cells, 17(4), 415-422. doi:10.1002/fuce.201600190

[35] Schneider, C. A., Rasband, W. S., \& Eliceiri, K. W. (2012). NIH image to ImageJ: 25 years of image analysis. Nature Methods, 9(7), 671-675. doi:10.1038/nmeth.2089

[36] https://www.gamry.com/application-notes/EIS/accurate-eis/. Last accessed 16 Jan. 2018

[37] Koch, S., Hansen, K. V., \& Johansen, B.S. (2005). Elchemea, https://www.elchemea.dk. Last accessed 16 Jan. 2018 
[38] Jiang, S. P. (2012). Nanoscale and nano-structured electrodes of solid oxide fuel cells by infiltration: Advances and challenges. International Journal of Hydrogen Energy, 37(1), 449470. doi:10.1016/j.ijhydene.2011.09.067

[39] Adler, S. B., Lane, J. A., \& Steele, B. C. H. (1996). Electrode kinetics of porous mixedconducting oxygen electrodes. Journal of the Electrochemical Society, 143(11), 3554-3564.

[40] Adler, S. B. (1998). Mechanism and kinetics of oxygen reduction on porous $\mathrm{La}_{1-\mathrm{x}} \mathrm{Sr}_{\mathrm{x}} \mathrm{CoO}_{3-\delta}$ electrodes. Solid State Ionics, 111(1-2), 125-134.

[41] Hjalmarsson, P., Søgaard, M., \& Mogensen, M. (2009). Oxygen transport properties of dense and porous $\left(\mathrm{La}_{0.8} \mathrm{Sr}_{0.2}\right)_{0.99} \mathrm{Co}_{0.8} \mathrm{Ni}_{0.2} \mathrm{O}_{3-\delta}$. Solid State Ionics, 180(23-25), 1290-1297. doi:10.1016/j.ssi.2009.07.012

[42] Jacobsen, T., Hendriksen, P. V., \& Koch, S. (2008). Diffusion and conversion impedance in solid oxide fuel cells. Electrochimica Acta, 53(25), 7500-7508. doi:10.1016/j.electacta.2008.02.019

[43] Kournoutis, V. C., Tietz, F., \& Bebelis, S. (2009). AC impedance characterisation of a $\mathrm{La} 0.8 \mathrm{Sr}_{0.2} \mathrm{Co}_{0.2} \mathrm{Fe}_{0.8} \mathrm{O}_{3-\delta}$ electrode. Fuel Cells, 9(6), 852-860. doi:10.1002/fuce.200800120

[44] Nielsen, J., Jacobsen, T., \& Wandel, M. (2011). Impedance of porous IT-SOFC LSCF:CGO $\begin{array}{llll}\text { composite cathodes. } & \text { Electrochimica } & \text { 7963-7974. }\end{array}$ doi:10.1016/j.electacta.2011.05.042

[45] Esquirol, A., Brandon, N. P., Kilner, J. A., \& Mogensen, M. (2004). Electrochemical characterization of $\mathrm{La}_{0.6} \mathrm{Sr}_{0.4} \mathrm{Co}_{0.2} \mathrm{Fe}_{0.8} \mathrm{O}_{3}$ cathodes for intermediate-temperature SOFCs. Journal of the Electrochemical Society, 151(11), A1847-A1855. doi:10.1149/1.1799391

[46] Dusastre, V., \& Kilner, J. A. (1999). Optimisation of composite cathodes for intermediate temperature SOFC applications. Solid State Ionics, 126(1), 163-174. doi:10.1016/S0167-2738(99)00108-3

[47] Waller, D., Lane, J. A., Kilner, J. A., \& Steele, B. C. H. (1996). The effect of thermal treatment on the resistance of LSCF electrodes on gadolinia doped ceria electrolytes. Solid State Ionics, 86-88(PART 2), 767-772. doi:10.1016/0167-2738(96)00362-1

[48] Chen, J., Liang, F., Chi, B., Pu, J., Jiang, S. P., \& Jian, L. (2009). Palladium and ceria infiltrated $\mathrm{La}_{0.8} \mathrm{Sr}_{0.2} \mathrm{Co}_{0.5} \mathrm{Fe}_{0.5} \mathrm{O}_{3-\delta}$ cathodes of solid oxide fuel cells. Journal of Power Sources, 194(1), 275-280. doi:10.1016/j.jpowsour.2009.04.041

[49] Steele, B. C. H., \& Bae, J. -. (1998). Properties of $\mathrm{La}_{0.6} \mathrm{Sr}_{0.4} \mathrm{Co}_{0.2} \mathrm{Fe}_{0.8} \mathrm{O}_{3-\mathrm{x}}$ (LSCF) double layer cathodes on gadolinium-doped cerium oxide (CGO) electrolytes II. role of oxygen exchange and diffusion. Solid State Ionics, 106(3-4), 255-261.

[50] Jud, E., \& Gauckler, L. J. (2005). The effect of cobalt oxide addition on the conductivity of $\mathrm{Ce}_{0.9} \mathrm{Gd}_{0.1} \mathrm{O}_{1.95}$. Journal of Electroceramics, 15(2), 159-166. doi:10.1007/s10832-005-2193-3 
[51] Lou, X., Wang, S., Liu, Z., Yang, L., \& Liu, M. (2009). Improving $\mathrm{La}_{0.6} \mathrm{Sr}_{0.4} \mathrm{Co}_{0.2} \mathrm{Fe}_{0.8} \mathrm{O}_{3-\delta}$ cathode performance by infiltration of a $\mathrm{Sm}_{0.5} \mathrm{Sr}_{0.5} \mathrm{CoO}_{3-\delta}$ coating. Solid State Ionics, 180(23-25), 1285-1289. doi:10.1016/j.ssi.2009.06.014

[52] Hayd, J., \& Ivers-Tiffée, E. (2013). Detailed electrochemical study on nanoscaled La ${ }_{0.6} \mathrm{Sr}$ ${ }_{0.4} \mathrm{CoO}_{3-\delta} \mathrm{SOFC}$ thin-film cathodes in dry, humid and $\mathrm{CO}_{2}$-containing atmospheres. Journal of the Electrochemical Society, 160(11), F1197-F1206. doi:10.1149/2.026311jes

[53] Almar, L., Szász, J., Weber, A., \& Ivers-Tiffée, E. (2017). Oxygen transport kinetics of mixed ionic-electronic conductors by coupling focused ion beam tomography and electrochemical impedance spectroscopy. Journal of the Electrochemical Society, 164(4), F289-F297. doi:10.1149/2.0851704jes

[54] Hayd, J., Yokokawa, H., \& Ivers-Tiffée, E. (2013). Hetero-interfaces at nanoscaled $(\mathrm{La}, \mathrm{Sr}) \mathrm{CoO}_{3-\delta}$ thin-film cathodes enhancing oxygen surface-exchange properties. Journal of the Electrochemical Society, 160(4), F351-F359. doi:10.1149/2.017304jes

[55] Dieterle, L., Bockstaller, P., Gerthsen, D., Hayd, J., Ivers-Tiffée, E., \& Guntow, U. (2011). Microstructure of Nanoscaled $\mathrm{La}_{0.6} \mathrm{Sr}_{0.4} \mathrm{CoO}_{3-\delta}$ Cathodes for Intermediate-Temperature Solid Oxide Fuel Cells. Advanced Energy Materials, 1, 249-258. doi:10.1002/aenm.201000036 